\title{
PENGARUH MODEL PEMBELAJARAN MIND MAPPING TERHADAP KEMAMPUAN MENENTUKAN STRUKTUR TEKS NEGOSIASI
}

\author{
Diyah Nurul Qotimah, Hannan Nawawi \\ Universitas Dr. Soetomo \\ Jalan Semolowaru 84 Surabaya \\ Email: eleonora.yosephina@gmail.com
}

\begin{abstract}
Abstrak
Penelitian ini bertujuan untuk mengetahui pengaruh model pembelajaran Mind Mapping dalam meningkatkan kemampuan menentukan struktur teks negosiasi kelas X SMK IKIP Surabaya. Berdasarkan hasil observasi pada saat awal praktek mengajar (PPL) peneliti metemukan bahwa guru Bahasa Indonesia masih menggunakan model pembelajaran konvensional (ceramah) dan siswa enggan bertanya ketika diberi kesempatan untuk bertanya. Siswa juga pasif dalam pembelajaran Bahasa Indonesia dan hanya mengandalkan hasil pekerjaan temannya ketika diadakan diskusi kelas, hal tersebut dapat memengaruhi hasil belajar siswa. Penerapan model pembelajaran Mind Mapping dalam kegiatan pembelajaran diharapkan dapat menimbulkan interaksi yang tinggi antara guru dan siswa ataupun antara siswa itu sendiri. Inilah yang membuat peneliti tertarik untuk mengadakan penelitian guna mengetahui adakah penerapan model pembelajaran Mind Mapping dalam meningkatkan kemampuan menentukan struktur Teks Negosiasi pada siswa kelas X SMK IKIP Surabaya. Penelitian ini bersifat eksperimen dengan menggunakan pendekatan kuantitatif. Data yang digunakan olee peneliti yaitu data pretest dan posttest yang kemudian di uji dengan Independent Sample t-Test. Hasil perhitungan dengan software SPSS 19.00 adalah bahwa diperoleh hasil yaitu nilai probabilitas (Assymp. Sig 2 tailed) 0 kurang dari taraf signifikansi 5\%, model pembelajaran Mind Mapping berpengaruh terhadap kemampuan menentukan struktur teks negosiasi.
\end{abstract}

Keyword : Model Pembelajran, Mind Mapping, Teks Negosiasi .

\section{PENDAHULUAN}

Pendidikan adalah sebagai usaha sadar dan terencana untuk mewujudkan suasana belajar dan proses pembelajaran untuk peserta didik secara aktif mengembangkan potensi dirinya untuk memiliki kekuatan spiritual keagamaan, pengendalian diri, kepribadian, kecerdasan, akhlak mulia, serta keterampilan yang diperlukan dirinya dan masyarakat. Secara sederhana, Pengertian pendidikan adalah proses pembelajaran bagi peserta didik untuk dapat mengerti, paham, dan membuat manusia lebih kritis dalam berpikir. Seorang anak harus wajib belajar 12 tahun yaitu dari Sekolah Dasar selama enam tahun melanjutkan ke Sekolah Menengah Pertama selama tiga tahun dan terakhir Sekolah Menengah Atas atau Sekolah Menengah Kejuruan selama tiga tahun. Selama 12 tahun, siswa akan mempelajari sembilan mata pelajaran wajib. Salah satunya adalah mata pelajaran Bahasa Indonesia.

Mata pelajaran Bahasa Indonesia cenderung menjadi mata pelajaran menuntut siswa untuk membaca dan menyimak kemudian mengingat setiap materi yang telah disampaikan oleh guru. Hal ini dikarenakan hampir seluruh materi mata pelajaran Bahasa Indonesia setiap bab memiliki bacaan berupa cerita, sehingga menuntut siswa untuk lebih banyak membaca. Seharusnya dalam mengikuti mata pelajaran tersebut, yang diingat siswa berasal dari yang dibaca, dari yang didengar, dari yang dilihat, dari yang dilihat dan didengar, dari yang dikatakan, dan sebagian besar adalah dari yang dilakukan dan dikatakan.

Salah satu materi pada pelajaran Bahasa Indonesia yaitu Teks Negosiasi. Keterkaitan permasalahan pada materi Teks Negosiasi terletak pada penjabaran struktur Teks Negosiasi. Dalam hal ini siswa sering salah dalam menentukan struktur Teks Negosiasi. Hal ini dikarenakan siswa belum memahami apa yang disampaikan oleh guru. Usaha untuk meningkatkan keterampilan menulis struktur Teks Negosiasi diperlukan suatu media pengajaran yang efektif dan efisien. Selama ini, metode ceramah dan penugasan ternyata belum mampu mencapai hasil yang optimal. Saat melakukan proses belajar mengajar, pendidik atau guru harus menggunakan media dan model 
pembelajaran yang baik agar siswa dapat memahami apa yang diajarkan oleh guru atau pendidik. Model pembelajaran merupakan salah satu komponen penting yang menunjang keberhasilan proses pembelajaran. Ketepatan pemilihan model pembelajaran akan berdampak pada keberhasilan belajar siswa serta tercapainya tujuan pembelajaran. Model pembelajaran merupakan suatu desain pembelajaran yang dirancang untuk memperlancar proses pembelajaran. Seperti yang diungkapkan oleh Suprijono (2012:46) yang mengemukakan bahwa model pembelajaran ialah pola yang digunakan sebagai pedoman dalam merencanakan pembelajaran di kelas maupun tutorial. Model Pembelajaran adalah suatu perencanaan atau suatu pola yang digunakan sebagai pedoman dalam merencanakan pembelajaran di kelas. Model pembelajaran mengacu pada pendekatan pembelajaran yang akan digunakan, termasuk di dalamnya tujuan-tujuan pengajaran, tahap-tahap dalam kegiatan pembelajaran, lingkungan pembelajaran, dan pengelolaan kelas (Arends dalam Trianto, 2010: 51). Sedangkan menurut Joyce \& Weil (1971) dalam Sumantri, dkk (1999: 42) model pembelajaran adalah kerangka konseptual yang melukiskan prosedur yang sistematis dalam mengorganisasikan pengalaman belajar untuk mencapai tujuan pembelajaran tertentu, dan memiliki fungsi sebagai pedoman bagi para perancang pembelajaran dan para pengajar dalam merencanakan dan melaksanakan aktifitas belajar mengajar.

Model pembelajaran terus berkembang sebagai usaha untuk meningkatkan kualitas pendidikan dan kualitas pembelajaran. Kemampuan guru dalam merancang pembelajaran yang mampu mengoptimalkan hasil belajar siswa merupakan kunci tercapainya tujuan pembelajaran. Banyak model pembelajaran yang menekankan pada keaktifan siswa di dalam proses pembelajaran, diantaranya adalah Mind Mapping. Mind Mapping adalah satu pengembangan model pembelajaran kooperatif yang memanfaatkan otak sebagai pusat pemerolehan informasi oleh siswa dengan cara memetakan pemikirannya terhadap informasi yang terdapat pada materi yang sedang dipelajari dan yang telah dipelajari/diingat sebelumnya sehingga siswa dapat dengan mudah memahami materi yang sedang dibahas. Sejalan dengan itu, menurut Mahmuddin (2009: 3) mengemukakan bahwa Model pembelajaran kooperatif tipe Mind Mapping merupakan suatu teknik grafik yang sangat ampuh dan menjadi kunci yang universal untuk membuka potensi dari seluruh otak, karena menggunakan seluruh keterampilan yang terdapat pada bagian neo-korteks dari otak atau yang lebih dikenal sebagai otak kiri dan otak kanan.

Model pembelajaran Mind Mapping merupakan salah satu model pembelajaran inovatif yang diharapkan dapat melibatkan siswa secara aktif dalam pembelajaran. Menurut Shoimin (2014: 105), "Model pembelajaran Mind Mapping adalah model pembelajaran yang meminta siswa untuk membuat Mind Mapping (peta pikiran), sehingga memungkinkan siswa mengidentifikasi dengan jelas dan kreatif apa yang telah dipelajari atau apa yang tengah direncanakan". Terdapat banyak kelebihan dari metode Mind Mapping (Peta Pikiran) karena model pembelajaran kooperatif tipe Mind Mapping melibatkan kedua sisi otak yaitu menggunakan gambar, warna, dan imajinasi (wilayah otak kanan) bersamaan dengan kata, angka, logika (wilayah otak kiri) sehingga, belajar akan menjadi lebih menyenangkan. Salah satu kelebihan Mind Mapping (Peta Pikiran) adalah dapat membantu siswa dalam banyak hal, seperti memacu kreativitas, pemahaman dan daya ingat siswa. Berikut pendapat para ahli tentang kelebihan Mind Mapping (Peta Pikiran).

Maghfiroh (2009: 45) mengemukakan kelebihan Mind Mapping (Peta Pikiran) sebagai berikut: (1) Memudahkan kita melihat gambaran keseluruhan, (2) membantu otak untuk: mengatur, mengingat, membandingkan, dan membuat hubungan, (3) memudahkan menambahkan informasi baru, (4) pengkajian ulang bisa lebih cepat, (5) setiap peta bersifat unik. Selain memiliki kelebihan, di dalam penerapan model pembelajaran kooperatif tipe Mind Mapping terdapat beberapa kelemahan (Santoso, 2011: 5) yaitu: (1) hanya siswa yang aktif yang terlibat, (2) tidak sepenuhnya siswa yang belajar, dan (3) jumlah detail informasi tidak dapat dimasukkan.

Berdasarkan hasil observasi pada saat awal praktek mengajar (PPL) ditemukan bahwa guru Bahasa Indonesia masih menggunakan model pembelajaran konvensional (ceramah) dan siswa enggan bertanya ketika diberi kesempatan untuk bertanya. Siswa beranggapan bahwa Bahasa Indonesia adalah pelajaran yang membosankan karena minimnya media pembelajaran yang digunakan oleh guru. Siswa juga pasif dalam pembelajaran Bahasa Indonesia dan hanya mengandalkan hasil pekerjaan 
temannya ketika diadakan diskusi kelas, hal tersebut dapat memengaruhi hasil belajar siswa.

Penerapan model pembelajaran Mind Mapping dalam kegiatan pembelajaran diharapkan dapat menimbulkan interaksi yang tinggi antara guru dan siswa ataupun antara siswa itu sendiri. Hal ini akan mengakibatkan suasana kelas menjadi aktif serta kondusif, dimana masing - masing siswa dapat menunjukkan kemampuannya seoptimal mungkin dengan banyak melakukan aktivitas - aktivitas belajar yang ditunjukkan dengan berbagai hal dalam proses belajar di kelas. Aktivitas yang timbul dari siswa akan mengakibatkan pula terbentuknya pengetahuan dan keterampilan yang akan mengarah pada peningkatan hasil belajar di sekolah.

Inilah yang membuat peneliti tertarik untuk mengadakan penelitian guna mengetahui adakah penerapan model pembelajaran Mind Mapping dalam meningkatkan kemampuan menentukan struktur Teks Negosiasi pada siswa kelas X SMK IKIP Surabaya.

\section{METODE PENELITIAN}

Jenis penelitian ini adalah penelitian eksperimen dengan pendekatan penelitian kuantitatif. Penelitian ini melibatkan dua kelompok yaitu kelompok eksperimen dan kelompok kontrol. Pada penelitian ini yang mendapatkan perlakuan kelompok eksperimen diberi model pembelajaran Mind Mapping sedangkan pada kelompok kontrol menggunakan metode ceramah. Penelitian ini bertempat di SMK IKIP Surabaya. Untuk mendapatkan data yang akurat, maka penelitian dilaksanakan dalam empat tahap, yaitu tahap persiapan, tahap pre test, tahap pelaksanaan, dan tahap post test. alam penelitian ini, peneliti menggunkan metode tes tertulis untuk pre test dan yang nantinya digunakan adalah berupa soal tes tertulis untuk pre test dan post test. tes ini dilakukan untuk mengukur seberapa besar siswa mampu menentukan struktur teks negosiasi ketika sebelum dan sesudah pembelajaran pada kelas eksperimen dan kelas kontrol, tes awal (pretes) bertujuan untuk mengetahui kemampuan awal kelas eksperimen dan kelas kontrol, sedangkan tes akhir (post-tes) dilakukan untuk melihat peningkatan kemampuan siswa pada dua kelas tersebut setelah diberiperlakuakn yang berbeda dalam proses belajar mengajar, dan untuk tes tertulis ini dibuat 10 butir soal dalam bentuk essay, sebelum instrumen tes hasil belajar digunakan dalam penelitian, maka instrumen tersebut diuji cobakan tujuan untuk mengetahui gambaran tentang terpenuhi atau tidaknya syaratsyarat instrumen sebagai alat pengumpulan data yang baik, kemudian divalidasi, direvisi, dan validasi ahli, kemudian soal ini digunakan untuk penelitian. Untuk menguji hipotesis ini digunakan uji normaloitas, uji homogenitas, dan two independent sample t-test.

\section{HASIL DAN PEMBAHASAN \\ Hasil Penelitian}

Pada awal penelitian dilakukan pengumpulan data nilai pretest pada kelas eksperimen. Data ini digunakan untuk data nilai awal kemampuan siswa sebelum diterapkan perlakuan model pembelajaran Mind Mapping pada kelas eksperimen. Setelah pengumpulan data pretest, siswa diberikan materi struktur teks negosiasi dengan menggunakan model pembelajaran Mind Mapping. Pada tahap akhir penelitian dilakukan pengumpulan data nilai posttest yang digunakan untuk mengetahui nilai siswa seelah diterapkannya model pembelajaran Mind Mapping. Nilai hasil pretest dan posttest tersebut diuji datanya dengan menggunakan softwre SPSS 19 dengan tujuan untuk mengetahui ada perbedaan atau tidak kemampuan awal siswa dengan kemampuan akhir setelah diterapkan model pembelajaran Mind Maping. Berikut ini adalah hasil uji normalitas dengan menggunakan Komlmogrov-Smirnov Test pada kelompok kontrol dan kelompok eksperimen pada nilai pretes dan postest dengan taraf signifikan 5\%.

Tabel 1. Hasil Uji Kolmogrov-Smirnov Test

\begin{tabular}{|l|c|c|}
\hline \multicolumn{1}{|c|}{ Aspek } & $\begin{array}{c}\text { Kelompok } \\
\text { kontrol }\end{array}$ & $\begin{array}{c}\text { Kelompok } \\
\text { eksperimen }\end{array}$ \\
\hline Banyak siswa & 33 & 33 \\
\hline Rata-rata pretest & 44,36 & 44.09 \\
\hline Rata-rata postest & 68,94 & 77,58 \\
\hline $\begin{array}{l}\text { Assymp (Sig. 2 } \\
\text { Tailed) pada pretest }\end{array}$ & 0,818 & 0,994 \\
\hline $\begin{array}{l}\text { Assymp (Sig. 2 } \\
\text { Tailed) pada postest }\end{array}$ & 0,270 & 0,285 \\
\hline
\end{tabular}

Berdasarkan tabel di atas, maka diperoleh nilai rata-rata pretest pada kelompok eksperimen adalah 44,09 dan kelompok kontrol adalah 44,36. Rata-rata postest untuk kelompok eksperimen adalah 77,58 dan kelompok kontrol adalah 68,94. Selanjutnya, untuk nilai probabilitas pada KolmogrovSmirnov-Test untuk nilai pretest diperoleh 0,818 pada kelompok kontrol dan 0,994 . Keduanya memiliki nilai probabalitas > 
5\%. Artinya sampel berasal dari populasi yang berdistribusi normal. Selanjutnya, untuk nilai postest diperoleh besar probabilitas untuk kelompok kontrol adalah 0,270 dan kelompok eksperimen 0,285. Hal ini juga mengartikan bahwa sampel berasal dari populasi yang berdistribusi normal.

Selanjutnya, uji homogenitas varians dengan tujuan untuk mengetahui apakan varias dari kedua sampel homogen atau tidak. Berikut ini hasil uji homogenitas variances

Tabel 2. Hasil Test of Homogenity Variances

\begin{tabular}{|c|c|c|}
\hline Aspek & Pretest & Post Test \\
\hline Levene Statistic & 0,167 & 2,658 \\
\hline \begin{tabular}{|lll}
$\begin{array}{l}\text { Assymp. } \\
\text { tailed) }\end{array}$ & Sig & \\
(2
\end{tabular} & 0,684 & 0,108 \\
\hline
\end{tabular}

Berdasarkan hasil analisis di atas, diperoleh nilai Levene Statistic saat pretest ada;ah 0,167 dan besar nilai probabilitas (Assymp. Sig (2 tailed)) adalah 0,864 lebih besar dari taraf sigunifikansi $5 \%$ artinya sampel penelitian memiliki varians yang sama atau homogen. Sedangkan pada saat postest diperoleh nilai levene statistic pada saat pretest adalah 2,568 dan besar nilai probabilitas adalah 0,108 lebih dari $5 \%$ artinya variasnya juga sama atau homogen.

Selanjutnya, hasil uji statistik dengan menggunakan Two Independent Sample t-Test. Uji ini dilakukan pada nilai pretest dengan tujuan untuk mengetahui apakah kemampuan dua kelompok sama atau tidak. Berikut ini hasil uji tersebut.

Tabel 3. Hasil Two Indendent Sample t-test pada nilai pretest

\begin{tabular}{|c|c|c|}
\hline Assymp. (Sig 2 Tailed) & $\mathbf{t}_{\text {hitung }}$ & df \\
\hline 0,355 & $-0,931$ & 64 \\
\hline
\end{tabular}

Berdasarkan hasil uji statistik diperoleh nilai probabilitas 0,355 lebih dari taraf signifikansi $5 \%$ artinyaa tidak ada perbedaan rata-rata nilai kelompok konrol dan kelompok eksperimen atau dengan kata lain kelompok kontrol dan kelompok eksperimen memiliki kemampuan yang sama sebelum diberikan perlakuan.

Ui statistik dengan menggunakan Two Independent Sample t-Test juga dilakukan pada hasil postest. Hal ini dilakukan dengan tujuan untuk mengetahui apakah ada perbedaan ratarata setelah diterapkan pembelajaran model mind-mapping pada kelompok eksperimen. Berikut ini hasil uji tersebut.
Tabel 4. Hasil Two Indendent Sample t-test pada nilai postest

\begin{tabular}{|c|c|c|}
\hline $\begin{array}{c}\text { Assymp. (Sig 2 } \\
\text { Tailed) }\end{array}$ & $\mathbf{t}_{\text {hitung }}$ & df \\
\hline 0 & 4,497 & 64 \\
\hline
\end{tabular}

Berdasarkan hasil uji statistik diperoleh nilai probabilitas 0 kurang dari taraf signifikansi 5\% artinya ada perbedaan rata-rata kelompok kontrol dan kelompok eksperimen atau dengan kata lain ada pengaruh model pembelaran mindmapping denga kemampuan menentukan teks struktur negosiasi.

\section{Pembahasan}

Pengumpulan data nilai pretest pada penelitian ini dilakukan sebelum memberikan materi struktur teks negosiasi. Data nilai pretest digunakan untuk melihat kesamaan kemampuan awal antara siswa kelas eksperimen dan siswa kelas kontrol. Data nilai pretest kemudian dilakukan uji prasyarat yaitu uji normalitas dan uji homogenitas varians dengan menggunakan software SPSS 19. Dari hasil pengujian dengan uji-t dua sis diperoleh nilai probablitas 0,355 lebih dari taraf signifikansi $5 \%$ artinya tidak ada perbedaan kemampuan awal siswa yang signifikan antara kelas eksperimen dengan kelas kontrol.

Setelah diketahui bahwa tidak ada perbedaan kemampuan awal yang signifikan antara kelas eksperimen dengan kelas kontrol maka peneliti dilanjutkan dengan penerapan perlakuan dengan menggunakan model pembelajaran Mind Mapping pada kelas eksperimen dan model pembelajaran konvensional pada kelas kontrol. Kemudian dilakukan posttest dengan uji t dua sisi diperoleh nilai probabilitas 0 kurang dari taraf signifikansi $5 \%$ artinya ada perbedaan rata-rata pada nilai test struktur teks negosiasi antara siswa yang diajar menggunakan model pembelajaran Mind Mapping dengan siswa yang diajar menggunakan model pembelajaran konvensional. Dari hasil pengujian, diketahui nilai rata-rata posttest kelas eksperimen sebesar 77,58 sedangkan nilai ratarata posttest keelas kontrol sebesar 68,94. Artinya, kelas eksperimen yang diajar menggunakan model pembelajaran Mind Mapping memiliki nilai lebih tinggi daripada kelas kontrol yang diajar dengan menggunakan model pembelajaran konvensioal.

Dari penjelasan sebelumnya, penerapan model pembelajaran Mind Mapping pada kelas eksperimen ternyata memberikan pengaruh 
terhadap kemampuan menentukan struktur teks negosiasi. Hal ini dikarenakan pada pembelajaran Mind Mapping siswa dibimbing untuk dapat menemukan kata kunci dan dijabarkan melalui peta konsepstruktur teks negosiasi. Siswa menjadi lebih aktif dalam berdiskusi dengan kelompok untuk memecahkan permasalahan yang diberikan oleh guru. Penggunaan alat peraga dalam proses pembelajaran membuat siswa lebih memahami materi yang diberikan oleh guru.

Sedangkan dengan menggunakan model pembelajaran Konvensional pada kelas kontrol ternyata juga ada pengaruh terhadap kemampuan menentukan struktur teks negosiasi. Namun, berdasarkan pengamatan peneliti peningkatan kemampuan menentukan struktur teks negosiasi pada kelas kontrol yang diajar menggunakan model pembelajaran konvensional tidak sebesar dengan kelas yang diajar menggunakan Mind Mapping dikarenakan pembelajaran masih berpusat pada guru sehingga materi belum tersampaikan secara merata. Ada banyak hal yang menunjukkan materi tidak diserap oleh siswa, antara lain kurangnya memperhatikan guru saat guru mennyampaikan materi, waktu pelajaran lebih sedikit dan siswa kurang antusias dalam mengikuti proses belajar mengajar. Siswa juga kurang mampu untuk dapat menyelesikan suatu permasalahan dalam soal dikarenakan siswa hanya terpacu pada contoh pengerjaan soal yang diberikan oleh guru.

Jadi dapat diketahui bahwa model pembelajaran Mind Mapping lebih baikdibanding model konvensional. Karena ada perbedaan kemmpuan menentukan struktur teks negosiasi antara siswa yang diajar menggunakan model pembelajaran Mind Mapping dengan siswa yang diajar menggunakanmodel Konvensional. Maka, dapat disimpulkan bahwa ada pengaruh moodel pembelajaran Mind Mapping terhadap kemampuan menntukan struktur teks negosiasi pada siswa kelas X SMK IKIP Surabaya.

\section{SIMPULAN}

Berdasarkan hasil analisis data dan pengujian hipotesis menggunakan Independent Sample t-Test dengan perhitungan menggunakan software SPSS 19 diperoleh hasil yaitu nilai probabilitas 0 kurang dari taraf signifikansi 5\% sehingga Artinya, model pembelajaran Mind Mapping berpengaruh terhadap kemampuan menentukan struktur teks negosiasi. Dari hasil pengujian juga diketahui nilai rata-rata postest kelas eksperimen sebesar 77,58 sedangkan nilai rata-rata posttest pada kelas kontrol sebesar 68,94 yang artinya kelas eksperimen yang diajar menggunakan model pembelajaran Mind Mapping memiliki lebih tinggi daripada kelas kontrol yang diajae dengan model pembelajaran konvensional. Karena ada perbedaan kemampuan menentukan struktur teks negosiasi antara siswa yang diajar menggunakan model pembelajaran Mind Mapping dengan siswa yang diajar menggunakan model pembelajaran konvensional, maka kesimpulan yang dapat dikemukakan dalam penelitian ini adalah ada pengaruh model pembelajaran Mind Mapping terhadap kemampuan menentukan sruktur teks negosiasi pada siswa kelas X SMK IKIP Surabaya.

\section{DAFTAR PUSTAKA}

Agus, Suprijono. 2012. Cooperative Learning: Teori dan Aplikasi Paikem. Yogyakarta: Pustaka Pelajar.

Alwi Hasan, dkk. 2005. Kamus Besar Bahasa Indonesia. Jakarta: Departemen Pendidikan Nasional Balai Pustaka.

Arends. 2011. dalam Trianto. Mendesain Model Pembelajaran Inovatif-Progresif. Ed ke 4. (hal.41) Jakarta : Kencana.

Arikunto, Suharsimi. 2006. Prosedur Penelitian Suatu Pendekatan Praktik. Jakarta: PT. Rineka Cipta.

Mahmuddin. 2009. Pembelajaran Berbasis Peta Pikiran (Mind Mapping). Tersedia :http://mahmuddin.wordpress.com/2009/ $12 / 01$

Santoso, E.B. (2011). Model Pembelajaran Mind Mapping. [Online]. Tersedia: https:raseko.blogspot.com/2011/05/modelpembelajaran-mindmapping.html Mei 2018].

Sumantri, Mulyani dan Permana, Johan. 1999. Strategi Belajar Mengajar, Jakarta: Direktorat Jendral Pendidikan Tinggi.

Trianto. 2010. Mendesain Model Pembelajaran Inovatif-Progresif. Jakarta: Kencana.

Shoimin, Aris. 2014. 68 Model Pembelajaran INOVATIF dalam Kurikulum 2013. Yogyakarta: AR-RUZZ MEDIA. 
Volume 5 No. 2 METALINGUA

Oktober 2020 Jurnal Pendidikan Bahasa dan Sastra Indonesia 